\title{
THE CREATIVITY OF THE EARLY CHILDHOOD EDUCATION'S TEACHERS IN CREATING AN \\ ANIMATION MEDIA WEB-BASED IN KOTO TANGAH PADANG
}

\author{
KREATIFITAS PENDIDIK PAUD \\ MEMBUAT MEDIA PEMBELAJARAN \\ ANIMASI BERBASIS WEB DI \\ KECAMATAN KOTO TANGAH KOTA \\ PADANG
}

Jurnal Pendidikan Luar Sekolah

http://kolokium.ppj.unp.ac.id/

Jurusan Pendidikan Luar Sekolah

Fakultas Ilmu Pendidikan

Universitas Negeri Padang

Sumatera Barat, Indonesia

Volume 7, Nomor 2, Oktober 2019

DOI: $10.24036 /$ kolokium-pls.v7i2.355

\author{
Wirdatul Aini, ${ }^{1,2}$, Setiawati', Alim Harun Pamungkas ${ }^{1}$ \\ ${ }_{1}^{1}$ Jurusan Pendidikan Luar Sekolah Fakultas Ilmu Pendidikan Universitas Negeri Padang \\ ${ }^{2}$ Email: wirdatulaini@fip.unp.ac.id
}

\begin{abstract}
One of the success of the Early Childhood Education Institution in society is based on the teacher's factor. The problem facing by the Early Childhood Education Institution in the sub-district of Koto Tangah is the lack of the creativity of the teachers to use modern media that will motivate children to play while learning. Until now, Early Childhood Education teachers still use traditional media in the teaching and learning process, when it looks outdated and less able to motivate children in learning. This training aims to help the teachers to be creative Early Childhood Education's teachers in making an animation learning media Web-based. Through the training of animation learning media Webbased, the teachers can improve their ability in applying various media. Skill training method in making an animation media-based uses; (1) speech method is used to deliver the material theoretically about the concept of Early Childhood Education and the learning characteristics, (2) discussion method is used by the Early Childhood Education's teachers to discuss about how to make an animation media web-based, (3) experiment/ practice method is used to train the Early Childhood Education's teachers in having an ability in making an animation media, each teacher tries to create an animation media web-based directly. The subject of this research is the 21 teachers, taken from each delegation of the Early Childhood Education Institution in Koto Tangah, Padang. The result of this research for the community can be described: (1) Early Childhood Education's teachers comprehend characteristics and learning strategies for early childhood, (2) some of them have already skilled, creative in creating web-based animation learning media. It is suggested to the school to always motivate and facilitate the Early Childhood Education's teachers in creating a good learning media following the advancement of science and technology. The Early Childhood Education's teachers are expected to have continuous training to improve their creativity in creating a good and varies learning media.
\end{abstract}

Keywords: Creativity, Learning Media, Web-Based Animation 


\begin{abstract}
ABSTRAK
Keberhasilan lembaga Pendidikan Anak Usia Dini (PAUD) di masyarakat salah satu di antaranya ditentukan dari faktor pendidik. Permasalahan yang dialami lembaga PAUD di Kecamatan Koto Tangah adalah rendahnya kreatifitas pendidik untuk menghasilkan media yang lebih modern saat ini, yang dapat lebih memotivasi anak untuk bermain sambil belajar. Pendidik PAUD saat ini masih menggunakan media tradisional dalam kegiatan pembelajaran dan kelihatan sudah usang dan kurang dapat memotivasi anak dalam belajar. Pelatihan ini bertujuan untuk menghasilkan pendidik PAUD yang kreatif dapat meningkatkan kualitas pembelajaran. Melalui pelatihan media berbasis animasi pendidik akan dapat meningkatkan keterampilannya menghasilkan media yang bervariasi. Metode pelatihan keterampilan membuat media berbasis animasi ini digunakan; (1) metode ceramah digunakan untuk penyampaian materi secara teoritis tentang konsep pendidikan anak usia dini dan karakteristik pembelajarannya, (2) metode diskusi digunakan pendidik PAUD berdiskusi tentang cara membuat media animasi berbasis web, (3) metode praktik/eksperimen digunakan melatih pendidik PAUD untuk terampil membuat media animasi, masing-masing pendidik mencoba secara langsung membuat media animasi berbasis web. Sasaran kegiatan pengabdian ini adalah pendidik PAUD berjumlah 21 orang, diambil masing-masing satu orang perwakilan lembaga dari 21 lembaga PAUD yang ada di Kecamatan Koto Tangah Kota Padang. Hasil pengabdian kepada masyarakat ini dapat digambarkan: (1) pendidik PAUD memahami karakteristik, dan strategi pembelajaran anak usia dini (2) sebagian dari pendidik PAUD sudah terampil, kreatif membuat media pembelajaran animasi berbasis web. Disarankan kepada mitra untuk selalu memotivasi, dan memfasilitasi pendidik PAUD dalam menghasilkan media pembelajaran yang berkualitas sesuai dengan kemajuan ilmu dan teknologi. Pendidik PAUD diharapkan berlatih secara kontiniu untuk meningkatkan kreatifitasnya menghasilkan media pembelajaran yang berkualitas dan bervariasi.
\end{abstract}

Kata Kunci: Kreatifitas, Media Pembelajaran, Animasi Berbasis Web

\title{
PENDAHULUAN
}

Anak adalah pewaris cita-cita perjuangan bangsa yang merupakan sumber daya manusia yang sangat penting dalam mencapai keberhasilan pembangunan. Untuk menghasilkan anak sebagai sumber daya manuasi yang berkualitas, kebutuhan hidupnya perlu dipenuhi, yaitu hak dan kebutuhan akan makanan, zat-zat gizi, kesehatan, bermain, keutuhan emosional, pengembangan spiritual, moral, pendidikan serta memerlukan lingkungan keluarga dan lingkungan sosial yang mendukung bagi kelangsungan hidup, tumbuh kembang dan perlindungannya (Rasyid, 2015)

Bimbingan pendidikan terhadap anak dimulai dari anak usia dini, dan bahkan semenjak anak dalam kandungan sudah harus dimulai mendidik dengan cara mengonsumsi makanan bergizi, dan halal, untuk menghasilkan anak yang cerdas serta berbakat. Selanjutnya untuk pengembangan spiritual, emosional, sosial anak dilakukan oleh orang tua dengan membiasakan melakukan perbuatan yang baik, beribadah kepada Allah, serta melakukan komunikasi interaksi dengan orang lain (Hotimah \& Yanto, 2019).

Menurut Undang-Undang Sisdiknas No. 20 tahun 2003, pendidikan pada dasarnya dilaksanakan melalui tiga lembaga, yaitu lembaga keluarga, sekolah dan masyarakat. Pendidikan di dalam keluarga adalah dilaksanakan oleh orang tua sebagai pendidik kodrat dan pendidik utama. Pendidikan di sekolah adalah lembaga yang memberikan pendidikan kepada anak dengan cara terprogram sistematis dan dirancang secara lebih matang, untuk membantu pertumbuhan dan perkembangan anak. Selanjutnya pendididikan di dalam masyarakat 
sebagai lembaga yang sangat penting pula fungsinya sebagai pelengkap, penambah dan pengganti dari pendidikan formal dan informal.

Pendidikan anak usia dini merupakan pendidikan yang dilakukan untuk membimbing, mengasuh anak usia 0-6 tahun. Pasal 28 UU Sisdiknas 2003 Pendidikan anak usia dini (PAUD) dapat dilakukan melalui 2 jalur, yakni jalur formal dan nonformal. Pada jalur pendidikan nonformal berbentuk Kelompok Bermain, Taman Penitipan Anak (TPA), serta PAUD sejenis, seperti Pospaud, PAUD dalam keluarga dsb.

Berdasarkan data dari ketua HIMPAUDI (Himpunan Pendidik Anak Usia Dini) Jalur Pendidikan Nonformal Ibu Desi Susanti mengungkapkan di Kecamatan Koto Tangah terdapat 21 Lembaga PAUD Jalur Pendidikan Nonformal, dengan jumlah pendidik 44 orang. Keberhasilan pendidikan di lembaga PAUD di antaranya ditentukan oleh pendidik. Pendidik pada jalur nonformal masih banyak belum memiliki keterampilan, kreatif untuk membuat media pembelajaran yang sesuai dengan tumbuh kembang anak usia dini. Berdasarkan hasil observasi yang dilakukan tanggal 14, 15 Januari 2019 di beberapa PAUD di Kecamatan Koto Tangah Kota Padang teramati pendidik lebih banyak menggunakan media yang sederhana, sudah lama atau usang. Sementara saat sekarang diharapkan para pendidik juga mengikuti perkembangan ilmu dan teknologi baik dari metode pembelajaran yang digunakan maupun dari penggunaan media pembelajaran. Selanjutnya hasil wawancara dengan pendidik PAUD Mawar yang bernama Misnetri Liona di Kelurahan Air Pacah tanggal 14 Januari 2019 pendidik PAUD belum terampil membuat media pembelajaran, termasuk media pembelajaran berbasis animasi .

Rendahnya kratifitas pendidik PAUD nonformal dalam menciptakan media pembelajaran dibenarkan oleh ketua HIMPAUDI Kecamatan Koto Tangah dalam hal ini ibu Desi Susanti, dan hasil wawancara tanggal 24 Januari 2019 mengungkapkan ada beberapa faktor yang menyebabkan kurang kreatifnya pendidik PAUD dalam membuat/menciptakan media pembelajaran bagi anak usia dini di antaranya: (1) secara umum pendidik PAUD yang ada tersebut masih banyak berlatar belakang SLTA, jadi pengetahuan dan keterampilan mereka dalam menciptakan media pembelajaran masih kurang, (2) masih jarangnya diadakan pelatihan-pelatihan yang dilakukan oleh pihak-pihak terkait dalam hal menciptakan media pembelajaran inovatif bagi pengembangan anak, khususnya untuk pengembangan kognitif, dan (3) pelatihan-pelatihan yang sering dilakukan pihak terkait lebih banyak tentang pelatihan karakter, manajemen pengelolaan administrasi dsb. Untuk itu kami dari tim pengabdian UNP merasa terpanggil untuk memberikan pelatihan keterampilan membuat media pembelajaran animasi berbasis web untuk meningkatkan kreatifitas pendidik dalam menciptakan media pembelajaran.

Media pembelajaran sebagai perantara bagi guru untuk membantu menyampaikan pesan/materi kepada anak didik. Untuk itu media perlu diciptakan oleh guru sehingga menarik minat anak untuk belajar, termasuk penggunaan media yang saat sekarang ini, dengan media berbasis online, yaitu media animasi. Keberadaan media pembelajaran atau yang dikenal dengan alat permainan edukatif (APE) yang sangat memegang peranan penting dalam upaya stimulasi pendidikan anak usia dini. Media pembelajaran sangat penting untuk menunjang berbagai aspek perkembangan pada anak usia dini. Sesuai dengan ciri khas anak usia dini secara kognitf menurut Piaget dalam Padmodewo (2003) anak berada pada tahap pra operasional konkrit. Mereka baru bisa mengerti dan mudah memahami materi atau keterampilan yang diajarkan jika sensor motornya menyentuh apa yang diajarkan. Anak akan mengerti apa yang diajarkan pendidik jika mereka mengalami langsung, dan benda tersebut langsung mereka lihat/amati, dan dirasakan oleh anak. Pendapat di atas juga didukung oleh 
Sudjana dan Ahmad dalam Hapsari (2017) yang mengemukakan bahwa taraf berpikir manusia mengikuti tahap perkembangan dimulai dari berpikir konkrit menuju berpikir abstrak, dan dari berpikir sederhana ke berpikir konkrit kompleks. Penggunaan media pembelajaran erat hubungannya dengan tahapan berpikir karena melalui media pembelajaran hal-hal yang abstrak dapat menjadi konkrit, dan hal-hal yang kompleks dapat menjadi sederhana.

Berdasarkan pendapat dan penjelasan di atas, maka pendidik anak usia dini harusnya selalu memperhatikan keberadaan, serta penggunaan media dalam setiap kegiatan pembelajaran. Diharapkan penggunaan media yang digunakan juga bervariasi dan tidak monoton hanya menggunakan media tradisional atau sederhana. Penggunaan media yang bervariasi dalam pembelajaran juga akan dapat meningkatkan motivasi anak dalam belajar. Untuk itu kami dari Tim Pengabdian Jurusan pendidikan Luar Sekolah UNP akan memberikan pelatihan keterampilan membuat media berbasis online meningkatkan keterampilan pendidik untuk menciptakan media yang inovatif dan kreatif.

\section{METODE}

Berdasarkan sasaran dari kegiatan pengabdian ini adalah pendidik PAUD di Kecamatan Koto Tangah Kota Padang adalah orang dewasa, maka pendekatan pengabdian yang digunakan adalah pendekatan andragogi. Pendekatan andragogi dimaksudkan untuk dapat mengoptimalkan keterlibatan pendidik PAUD dalam kegiatan pelatihan. Kegiatan pelatihan akan terasa bermanfaat apabila pendidik merasakan kegiatan pelatihan membuat media merupakan kebutuhan yang sangat mendesak, dan sangat penting yang harus mereka miliki, sehubungan dengan tugas mereka untuk menstimulasi anak-anak PAUD agar tumbuh motivasinya untuk belajar sambil bermain. Kemudian penggunaan pendekatan partisipatif dalam penyampaian konsep dan teori pada pelatihan, dimaksudkan agar peserta lebih aktif baik dalam kegiatan memperoleh informasi secara individu dari instruktur maupun dalam kegiatan kelompok, sehingga dalam kegiatan pembelajaran dan pelatihan terjadi suasana yang kondusif, menyenangkan dan multi arah.

Secara teknis kegiatan pelatihan ini akan dilakukan secara klasikal dan secara individual. Kegiatan klasikal digunakan pada saat penyampaian teori dan konsep yang disampaikan oleh narasumber yang sudah ditetapkan untuk memberikan informasi, dan memandu dalam berdiskusi. Sementara kegiatan secara individual dilakukan dalam rangka melaksanakan praktik pembuatan media pembelajaran animasi untuk meningkatkan kreatifitas pendidik PAUD. Untuk lebih jelasnya metode pembelajaran yang digunakan dalam kegiatan pelatihan ini adalah sebagai berikut: Pertama, untuk penyamapaian materi secara teoritik berkaitan dengan konsep, teori-teori penjelasan tentang suatu pengetahuan digunakan metode ceramah, dengan tetap memperhatikan pendekatan partisipatif. Pada kegiatan ceramah ini diharapkan akan terjadi proses diskusi setelah penyampaian materi melalui metode ini.

Kedua, teknik diskusi sangat diperlukan dalam pelatihan ini. Karena berdasarkan sasaran kegiatan pelatihan ini adalah pendidik anak usia dini, mereka semua adalah orang dewasa yang sudah mengalami proses mendidik anak usia dini. Pendidik PAUD ini sudah merasakan suka duka menjadi pendidik PAUD dalam hal menstimulasi perkembangan anak usia dini. Oleh karena ini proses pembelajaran secara dua arah benar-benar terjadi pada kegiatan pelatihan, seingga berhasil secara optimal. Pelaksanaan teknik ini benar-benar efektif dalam setiap kegiatan penyampaian materi maupun dalam kegiatan pelatihan. Untuk orang 
dewasa saling berdiskusi untuk memantapkan pemahaman terhadap materi lebih penting untuk saling belajar, saling memberikan masukan dalam memperluas pengetahuan, ataupun keterampilan.

Ketiga, untuk melatih dan meningkatkan kemampuan dan keterampilan peserta pelatihan dalam membuat media animasi sehingga menghasilkan pendidik PAUD yang kreatif untuk dapat menstimulasi perkembangan anak usia dini. Masing-masing pendidik mencobakan membuat media animas berbasis web. Keempat, langkah pada teknik ini diawali dengan pemateri menunjukkan, cara/proses yang dilakukan untuk dapat terampil membuat media animasi. Selanjutnya langkah pertama memperlihatkan untuk login ke internet. Instruktur mempraktikkan bagaimana cara sampai login ke internet. Kemudian masingmasing peserta mencobakan, dan narasumber memberikan arahan sambil mencobakan. Langkah selanjutnya mencoba memilih di internet media yang akan dikembangkan. Misalnya tema pembelajarannya adalah binatang. Maka login ke binatang, maka akan dapat dikembangkan binatang yang dimaksud sesuai dengan tujuan pembelajaran. Kemudian instruktur akan mengembangkan gambar yang dipilih dalam berbagai aktifitas. Misalnya mengelompokkan binatang berkaki dua, berkaki empat dsb. Kemudian dikelompokkan dalam bentuk poster dan bentuk lain. Media animasi ini akan lebih dapat memotivasi anak untuk belajar sambil bermain dalam rangka pengembangan aspek kognitif, sosial emosional, bahasa, seni, dan motorik anak usia dini. Untuk kelancaran pelaksanaan kegiatan pelatihan lembaga mitra berperan sebagai fasilitator, yakni menyediakan tempat pelatihan, selanjutnya juga bertugas sebagai rekrutmen peserta pelatihan.

\section{HASIL PENELITIAN DAN PEMBAHASAN}

Pada bagian ini akan disajikan hasil yang telah dicapai setelah dilakukan kegiatan pelatihan keterampilan, di antaranya: ditinjau dari tujuan pelatihan peserta berpendapat bahwa mereka mengikuti keterampilan membuat media animasi berbasis web, sebagian besar 95\% adalah untuk memperoleh pengetahuan. Di samping itu tujuan mereka mengikuti kegiatan pelatihan adalah untuk memperoleh keterampilan $76 \%$ sangat setuju, dan 23\% peserta mengungkapkan setuju. Kemudian peserta berpendapat mereka mengikuti kegiatan keterampilan membuat media animasi berbasis web adalah untuk meningkatkan kreatifitas dalam pengembangan media pembelajaran untuk anak usia dini, 85,76\% sangat setuju, dan $14,28 \%$ setuju. Berkaitan dengan tujuan ikut pelatihan untuk membantu menumbuhkan motivasi belajar anak usia dini, $76 \%$ peserta berpendapat sangat setuju, dan $23.8 \%$ berpendapat setuju. Berdasarkan data yang diperoleh peserta mengikuti kegiatan pelatihan membuat media animasi berbasis web, untuk memperoleh, pengetahuan, keterampilan, meningkatkan kreatifitas, dan untuk dapat meningkatkan motivasi anak usia dini dalam belajar. Sejalan dengan itu Uno dalam Yanti (2018) mengemukakan bahwa tujuan pembelajaran merupakan rumusan perilaku yang dirmuskan dalam kegiatan pembelajaran mencakup pencapaian pengetahuan, keterampilan dan sikap.

Temuan pelatihan yang berkaitan dengan materi yang dilatihkan pada pelatihan membuat media pembelajaran animasi diperoleh hasil bahwa $52 \%$ peserta menjawab sesuai dengan kebutuhannya, dan $47 \%$ berpendapat setuju materi sesuai dengan kebutuhannya. Meteri pelatihan bermanfaat bagi mereka sangat setuju $71 \%$, setuju $28.57 \%$. Selanjutnya materi pelatihan sesuai dengan kebutuhan untuk masa yang akan datang, menjawab sangat setuju $71 \%$, dan setuju 28,5\%. Materi membuat media pembelajaran animasi saya berminat $71 \%$ peserta menjawab sangat setuju, dan 28.57 peserta menjawab setuju, hal ini dibuktikan 
peserta berminat dengan kehadiran peserta mengikuti kegiatan 100\%, atau hadir 21 orang setiap hari pelatihan. Kemudian materi pelatihan dalam bentuk praktik sebagian $57 \%$ peserta sangat memahami, dan 43,8\% peserta memahaminya. Sejalan dengan itu Winataputra dalam Pane \& Dasopang (2017) materi pembelajaran adalah sesuatu yang dibahas dalam pembelajaran, oleh karena itu materi haruslah: (1) ksesuaian bahan belajar dengan kebutuhan, (2) kemudahan isinya yakni mudah dimengerti, dipelajari, dipahami peserta, dan (3) menarik adalah bentuk dan isinya menarik warga belajar untuk belajar. Materi pelatihan media animasi berbasis web berdasarkan kebutuhan untuk membantu menyajikan materi untuk anak usia dini, media animasi ini menarik minat anak untuk belajar.

Berkaitan dengan metode pelatihan yang digunakan instrukur peserta berpendapat metode ceramah sangat setuju digunakan $52 \%$ peserta menjawab, dan $47.6 \%$ peserta menjawab setuju. Penggunaan metode ceramah oleh intruktur dimasudkan untuk menjelaskan langkah-langkah membuat media animasi berbasis web, dimulai dengan lgin ke internet, memilih program yang ditawarkan, dan mulai bekerja membuat media. Penggunaan metode diskusi pada pelatihan $52 \%$ peserta sangat setuju, dan $47,6 \%$ pesertta menjawab setuju. Melalui metode diskusi peserta saling belajar bersama mengenai materi yang sudah dilatihkan oleh instruktur. Dengan saling belajar secara berdikusi akan menambah terampil dan kreatif pendidik anak usia dini menghasilkan media yang menarik minat peserta. Metode pelatihan secara eksperimen peserta menjawab sangat setuju $66 \%$, dan peserta menjawab setuju metode ekperimen 33,7\%. Kemudian peserta menjawab metode ekperimen cocok digunakan dalam pelatihan membuat media animasi berbasis web, peserta menjawab sangat setuju $71 \%$, dan peserta menjawab setuju $28.57 \%$. Dengan berlatih secara individu melalui metode eksperimen menjadikan peserta/pendidik PAUD bertambah terampil dan kreatif untuk membuat media pembelajaran animasi berbasis web. Metode latihan menurut peserta 66\% sangat setuju digunakan, dan 33,3\% menjawab setuju. Dalam belajar membuat media pembelajaran animasi berbasis web metode latihan sangat penting digunakan. Menurut Wina dalam Sulkipani (2017) pemilihan metode dalam pembelajaran sangat tergantung kepada materi pelatihan/pembelajaran, dan tujuan pembelajaran. Jika tujuan pembelajaran untuk pencapaian keterampilan maka metode yang tepat digunakan adalah metode eksperimen dan metode latihan. Untuk kegiatan pelatihan membuat media pembelajaran animasi berbasis web metode eksperimen dan latihan sangat tepat digunakan.

Keberhasilan pelatihan keterampilan membuat media animasi berbasis web ditentukan oleh instruktur. Instruktur melayani peserta dengan menjawab pertanyaan yang dianggap sulit, $57 \%$ peserta sangat setuju, dan $47.61 \%$ peserta menjawab setuju. Kepribadian instruktur peserta menjawab 66\% sangat setuju instruktur ramah, dan 33,3\% instruktur setuju ramah. Instruktur memiliki kepribadian yang baik, menumbuhkan motivasi peserta menjawab sangat setuju 66\%, dan menjawab setuju 33.3\%. Sejalan dengan itu sumber belajar adalah segala sesuatu baik manusia maupun non manusia yang dapat menyampaikan pengetahuan, keterampilan dan sikap kepada peserta didik. Menurut Yusuf dalam Sudjana dalam Supriadi (2015) kriteria sumber belajar; (1) memiliki pengetahuan, keterampilan, dan sikap sesuai dengan materi yang diajarkan, (2) memahami strategi belajar pendidikan luar sekolah, dan dapat memilih strategi yang tepat yang sesuai dengan materi, (3) mampu mengelola pendidikan luar sekolah, dan (4) memiliki kepribadian yang baik. Sumber belajar pelatihan keterampilan membuat media pembelajaran animasi berbasis web memiliki kepribadian yang baik, ramah, dan memiliki pengetahuan, keterampilan, dan sikap yang akan dilatihkan kepada peserta. 
The Creativity of the Early Childhood Education's Teachers in Creating an Animation...

Kegiatan pelatihan membuat media pembelajaran animasi berbasis web dipengaruhi oleh faktor fasilitas, sarana, prasarana yang mendukung utuk pencapaian kegiatan pelatihan. Di antara faktor yang menentukan keberhasilan pelatihan adalah tempat belajar/pelatihan. Pelatihan dilakukan pada tempat yang nyaman $71 \%$ peserta menjawab sangat setuju, dan $28.57 \%$ peserta menjawab setuju tempat belajar nyaman. Ruangan yang digunakan untuk tempat berlatih luas, dapat menampung 21 orang peserta $52 \%$ sangat setuju, dan $42,8 \%$ menjawab setuju tempat dapat menampung peserta pelatihan. Berkaitan dengan akses internet $66 \%$ peserta menjawab sangat setuju, dan $33.3 \%$ menjawab setuju. Kemudian peralatan kursi tempat duduk peserta pelatihan tersedia $76 \%$ sangat setuju, dan $23.8 \%$ menjawab setuju. Dapat digambarkan bahwa fasilitas, sarana belajar tersedia untuk mendukung kegiatan pelatihan, termasuk akses internet dapat digunakan dengan lancar. Menurut Mappa 1984 pemilihan tempat belajar pada Pendidikan Luar Sekolah hendaknya memenuhi persyaratan di antaranya: (1) tempat belajar strategis, mudah dijangkau oleh peserta, (2) ruang belajar dapat menampung 5-20 orang peserta, (3) penempatan peralatan dan mobile memungkinkan dapat diubah sesuai dengan kebutuhan peserta, (4) pintu jendela hendaknya memudahkan terjadinya pertukarannudara dalam ruangan, (5) penerangan/lampu mencukupi, dan (6) tempat belajar aman untuk pelaksanaan kegiatan pelatihan.

Kegiatan pelatihan keterampilan membuat media pembelajaran animasi berbasis web, tergambar bahwa peserta sudah mulai terampil, 52\% jawaban sangat setuju, dan 47,6\% jawaban peserta setuju. Selanjutnya pelatihan membuat media animasi dapat meningkatkan kreatifitas pendidik PAUD 66\% peserta sangat setuju, dan $33.3 \%$ setuju pelatihan dapat meningkatkan kreatifitas peserta pelatihan. Berdasarkan pengamatan terhadap pelatihan membuat media pembelajaran animasi berbasis web, peserta pelatihan terlihat aktif berlatih menghasilkan media animasi yang diajarkan instruktur. Kreatifitas media yang dihasilkan peserta sudah mulai muncul. Dapat diambil kesimpulan bahwa dengan mengikuti pelatihan membuat media pembelajaran animasi berbasis web, sangat jelas dapat meningkatkan keterampilan, kreatifitas pendidik PAUD dalam menghasilkan media pembelajaran animasi berbasis web untuk anak usia dini.

\section{KESIMPULAN}

Berdasarkan temuan pelatihan keterampilan membuat media pembelajaran animasi berbasis web dapat disimpulkan, tingginya minat pendidik PAUD mengikuti kegiatan pelatihan, dan terbukti dari jumlah kehadiran seluruh peserta selama kegiatan dilaksanakan. Dari segi tujuan pelatihan keterampilan yang diberikan kepada pendidik PAUD agar terampil membuat media pembelajaran untuk anak usia dini, serta kretifitas pendidik PAUD dapat meningkat untuk menghasilkan media pembelajaran yang bervariasi, hal ini dibuktikan dengan produk media animasi berbasis web yang dihasilkan oleh pendidik PAUD. Kemudian ditinjau dari materi pelatihan yang dilatihkan oleh instruktur, sesuai dengan kebutuhan pendidik PAUD, menarik, serta mudah untuk dilaksanakan. Metode pelatihan yang digunakan instruktur untuk penyampaian materi, digunakan metode ceramah, menjelaskan materi pembuatan media pembelajaran animasi berbasis web, metode diskusi, digunakan peserta dapat saling belajar bersama tentang materi yang dilatihkan. Metode utama yang digunakan pelatih adalah metode eksperimen, masing-masing peserta berlatih membuat media animasi, sehingga peserta dapat terampil membuat media yang akan digunakan dalam kegiatan pembelajaran untuk anak usia dini. Berkaitan dengan instruktur pelatih keterampilan dapat melatih peserta dengan materi yang jelas, ramah, membimbing peserta, serta memiliki kepribadian yang baik. Selanjutnya tentang fasilitas yang berkaitan dengan peralatan yang 
digunakan, tempat pelatihan. Peralatan, fasilitas, dan tempat yang digunakan seperti meja, kursi untuk peserta dapat memanfaatkan fasilitas yang ada di Pusat Kegiatan Belajar Masyarakat (PKBM) Darma sebagai mitra pengabdian. Saran yang disampaikan kepada peserta pelatihan/pendidik PAUD agar selalu berlatih membuat media pembelajaran animasi berbasis web, dan dapat mengembangkannya secara mandiri untuk dapat meningkatkan keterampilan dan kreatifitas dalam membuat media pembelajaran yang bervariasi. Kepada mitra dalam hal ini Pusat Kegiatan Belajar Masyarakat (PKBM) agar selalu memotivasi pendidik untuk selalu belajar mengembangkan media pembelajarn yang digunakan untuk pembelajaran anak usia dini. Kepada HIMPAUDI (Himpunan Pendidik Anak Usia Dini), agar dapat mecari peluang-peluang yang dapat melatih pendidik PAUD untuk dapat mengembangkan dirinya sebagai pendidik PAUD.

\section{DAFTAR RUJUKAN}

Hapsari, A. E. (2017). Penerapan Model Pembelajaran Kooperatif Tipe Numbered Heads Together Berbantuan Media Interaktif untuk Meningkatkan Aktivitas dan Prestasi Belajar Siswa. Scholaria, 7(1), 1-9.

Hotimah, N., \& Yanto. (2019). Peran Orang Tua dalam Meningkatkan Kecerdasan Spiritual. Indonesia Journal of Learning Education and Counseling, 1(2), 85-93.

Padmodewo, S. (2003). Pendidikan Anak Prasekolah. Jakarta: Rineka Cipta.

Pane, A., \& Darwis Dasopang, M. (2017). Belajar dan Pembelajaran. FITRAH: Jurnal Kajian Ilmu-Ilmu Keislaman, 3(2), 333. https://doi.org/10.24952/fitrah.v3i2.945

Rasyid, H. (2015). Membangun Generasi Melalui Pendidikan Sebagai Investasi Masa Depan. Pendidikan Anak, IV (1), 565-581.

Sulkipani. (2017). Perencanaan Pembelajaran Pendidikan Kewarganegaraan (PKn) untuk Mengembangkan Kesadaran Bela Negara Mahasiswa. Jurnal Civics, 14(1), 51-62.

Supriadi, S. (2015). Pemanfaatan Sumber Belajar dalam Proses Pembelajaran. Lantanida Journal, 3(2), 127-139. Retrieved from https://jurnal.arraniry.ac.id/index.php/lantanida/article/download/1654/1206

Yanti, A. Y. (2018). Kemampuan Guru dalam Merumuskan Tujuan Pembelajaran PPKN di Sekolah Menengah Kejuruan Negeri 1 Sukoharjo. In Prosiding Seminar Nasional PPKn 2018 "Seminar Nasional Penguatan Nilai-Nilai Kebangsaan Melalui Pendidikan Kewarganegaraan Persekolahan dan Kemasyarakatan." Surakarta: Laboratorium PPKn FKIP UNS. 